\title{
Effects of Smoking on Hematological Parameters and Ferritin Levels
}

Sigaranın Hematolojik Parametreler ve Ferritin Düzeyleri Üzerindeki Rolü

\author{
๑ Rafiye Çiftçiler, ๑ Alper Güven* , • Ibrahim Celalettin Haznedaroğlu, ๑ Salih Aksu \\ Hacettepe University Faculty of Medicine, Department of Internal Diseases, Division of Hematology, Ankara, Turkey \\ *Hacettepe University Faculty of Medicine, Department of Internal Diseases, Ankara, Turkey
}

\section{Abstract}

\begin{abstract}
Aim: Cigarette smoking is associated with an increased risk of cardiovascular diseases, including coronary artery disease, peripheral vascular disease, ischemic heart disease, atherosclerosis, myocardial infarction, and stroke. Our aim was to define possible effects of smoking on hematological parameters as well as ferritin and transferrin saturation.
\end{abstract}

Methods: This study was performed in a retrospective manner. One hundred and forty-nine patients, who were admitted to Hacettepe University Hospitals between September 2018 and November 2018, were evaluated.

Results: There were 95 (63.7\%) healthy non-smokers and 54 $(36.3 \%)$ healthy smokers included in this study. The median age was 32 (18-61) years for all groups. There were $47(31.5 \%)$ males and $102(68.5 \%)$ females in this study. Hemoglobin $(p<0.001)$, hematocrit $(\mathrm{HCT}) \quad(p<0.001)$ and mean corpuscular volume $(\mathrm{MCV})(p=0.002)$ values were statistically significantly higher in smokers-group than in non-smokers group. Leukocyte $(p<0.001)$, neutrophil $(p=0.001)$ and lymphocyte $(p=0.04)$ counts were statistically significantly higher in smokers group compared to non-smokers group.

Conclusion: Our study showed that cigarette smoking has severe adverse effects on hematological parameters such as hemoglobin, leucocytes, lymphocytes, MCV and HCT. These alterations might be associated with a greater risk of developing secondary polycythemia, atherosclerosis, chronic obstructive pulmonary disease and cardiovascular diseases.

Keywords: Cigarette smoking, complete blood count, ferritin

Öz

\begin{abstract}
Amaç: Sigara içimi, koroner arter hastalığı, periferik vasküler hastalık, iskemik kalp hastalığı, ateroskleroz, miyokardiyal enfarktüs ve inme gibi kardiyovasküler hastalık riskinin artmasıyla ilişkilidir. Amacımız, sigaranın hematolojik parametrelerin yanı sıra ferritin ve transferrin satürasyonu üzerine olası etkilerini değerlendirmektir.
\end{abstract}

Yöntemler: Bu çalışma retrospektif olarak yapıldı. Eylül 2018 ile Kasım 2018 arasında Hacettepe Üniversitesi Hastaneleri'ne başvuran yüz kırk dokuz hasta değerlendirildi.

Bulgular: Çalışmaya $95(\% 63,7)$ sağlıklı sigara içmeyen ve 54 $(\% 36,3)$ sağlıklı sigara içicisi dahil edildi. Tüm yaş grupları için medyan yaş $32(18-61)$ idi. Bu çalışmada $47(\% 31,5)$ erkek ve 102 $(\% 68,5)$ kadın vardı. Sigara içen grupta hemoglobin $(p<0,001)$, HCT $(p<0,001)$ ve ortalama eritrosit hacmi (MCV) $(p=0,002)$, sigara içmeyenlere göre istatistiksel olarak anlamlı derecede yüksek bulundu. Sigara içmeyen grupta lökosit $(p<0,001)$, nötrofil $(p=0,001)$ ve lenfosit $(p=0,04)$ değerleri sigara içmeyenlere göre istatistiksel olarak anlamlı derecede yüksek bulundu.

Sonuç: Çalışmamızda sigara içmenin hemoglobin, lökosit, nötrofil, lenfosit, MCV ve HCT gibi hematolojik parametreler üzerinde ciddi olumsuz etkileri olduğu gösterilmiştir. Bu değişiklikler ikincil polisitemi, ateroskleroz, kronik obstrüktif akciğer hastalığı ve kardiyovasküler hastalıklar gelişme riski ile ilişkili olabilir.

Anahtar Sözcükler: Sigara içme, tam kan sayımı, ferritin
Address for Correspondence/Yazışma Adresi: Rafiye Çiftçiler, Hacettepe University Faculty of Medicine, Department of Internal Diseases, Division of Hematology, Ankara, Turkey Phone: +90 5055831798 E-mail: rafiyesarigul@gmail.com ORCID: orcid.org/0000-0001-5687-8531 Received/Geliş Tarihi: 13 December 2018 Accepted/Kabul Tarihi: 25 February 2019
${ }^{\circ}$ Copyright 2019 by The Medical Bulletin of istanbul Haseki Training and Research Hospital The Medical Bulletin of Haseki published by Galenos Yayınevi. Telif Hakkı 2019 ỉstanbul Haseki Eğitim ve Araştırma Hastanesi Haseki Tıp Bülteni, Galenos Yayınevi tarafından yayınlanmıştır. 


\section{Introduction}

Cigarette smoking is one of the leading causes of death throughout the world (1). Cigarette smoking is associated with an increased risk of cardiovascular diseases, including coronary artery disease, peripheral vascular disease (2), ischemic heart disease (3), atherosclerosis (4), myocardial infarction (4), and stroke (5). The certain mechanism of events-leading to these disorders in smokers are not clear, but it is supposed that these effects are caused by abnormalities in the blood rheology, inflammation, infection, oxidative stress, and changes in antithrombotic and fibrinolytic system (1). The parameters of complete blood count (CBC) consists of red cell distribution width (RDW), mean platelet volume (MPV) and those parameters obtained from a CBC can be used to calculate neutrophil-to-lymphocyte ratio (NLR) and platelet-tolymphocyte ratio (PLR). In the past, RDW was shown to be an independent predictor of mortality in patients with coronary artery disease (6). Some studies have reported that leukocyte count increased with the number of cigarettes smoked daily and decreased after cessation of smoking $(7,8)$. Additionally, platelet indices, such as platelet distribution width (PDW), MPV and plateletcrit (PCT), have been shown to be the biomarkers that may be altered in infections, respiratory and cardiovascular diseases $(9,10)$. In this study, we evaluated the association between hematological parameters and smoking status. Our aim was to define the possible effects of smoking on hematological parameters as well as ferritin and transferrin saturation (TS).

\section{Methods}

\section{Patients}

This study was performed in a retrospective manner. One hundred and forty-one patients, who were admitted to Hacettepe University Hospitals with varying symptoms between September 2018 and November 2018, were evaluated. Inclusion criteria in this study were being older than 18 years of age, having no chronic diseases such as diabetes mellitus, ischemic heart disease, peripheral vascular disease, active liver and kidney disease, chronic pancreatitis, gastrointestinal disease, inflammatory bowel diseases, hypertension, and any infectious or debilitating illness. In addition, patients, who were on medications such as antibiotics, steroids, thiazide diuretics, aspirin, nonsteroidal anti-inflammatory drugs, immunomodulatory drugs and drugs that may interfere with ferritin and $C B C$ parameters were excluded from the study. $C B C$, ferritin and TS were evaluated in smokers and non-smokers. Blood samples were drawn between 9 and 12 a.m. The smokers were classified into light, moderate and heavy based on the number of pack years as 10-14, 15-19, and $\geq 20$, respectively (11). Informed consent was obtained from all the subjects.

This study was approved by the Hacettepe University Ethics Committee (08.01.2019/GO 19/04).

\section{Statistical Analysis}

Statistical analyses were performed using the SPSS software version 25 . The variables were investigated using visual (histograms, probability plots) and analytical methods (Kolmogorow-Simirnov test/Shapiro-Wilk test) to determine whether or not they were normally distributed. The groups were compared using the Student's t-test for parameters with normal distribution or the MannWhitney test for parameters with non-normal distribution. Descriptive analyses were presented using means and standard deviations for normally distributed variables. A $p$ value of less than 0.05 was considered statistically significant.

\section{Results}

There were 95 (63.7\%) healthy non-smokers and 54 $(36.3 \%)$ healthy smokers included in this study. The median age of the participants was 32 (18-61) years. There were 47 (31.5\%) males and 102 (68.5\%) females in this study. Age, gender, CBC, ferritin and TS according to smoking status are shown in Table 1. There was no statistically significant difference in age between the two groups $(p=0.1)$. The male-to-female ratio was significantly higher in the smoker group ( $p=0.01)$. Hemoglobin $(\mathrm{Hb})(p<0.001)$, hematocrit $(\mathrm{HCT})(p<0.001)$ and mean corpuscular volume (MCV) $(p=0.002)$ values were statistically significantly higher in smokers-group than in non-smokers group. Vice versa, RDW was lower in the smokers-group than in non-smokers group $(p=0.001)$. Leukocyte $(p<0.001)$, neutrophil $(p=0.001)$ and lymphocyte counts $(p=0.04)$ were statistically higher in the smokers group compared to non-smokers group. There was no statistically significant difference in parameters of platelet indices between the groups. There was also no statistically significant difference in ferritin $(p=0.23)$ and TS $(p=0.41)$ values between the two groups.

As the smokers were classified into three groups according to smoking intensity as light, moderate and severe smokers (Figure 1), it was found that the male-tofemale ratio increased significantly with smoking intensity $(p=0.004)$. The hematological parameters compared between light, moderate and heavy smokers showed that the level of $\mathrm{Hb}(p=0.01), \mathrm{HTC}(p=0.01)$, lymphocyte $(p=0.04)$ and thrombocyte counts $(p=0.01)$ were significantly increased as smoking intensity rose. However, the MCV levels $(p=0.18)$ and leukocyte $(p=0.05)$ and neutrophil $(p=0.21)$ counts did not change significantly with the intensity of smoking as shown in Table 2. Ferritin and TS did not change with the intensity of smoking. 
Table 1. Baseline characteristics and comparison of hematological parameters between smokers and non-smokers

\begin{tabular}{|c|c|c|c|}
\hline Parameters & Smokers & Non-smokers & $\mathbf{p}$ \\
\hline $\mathbf{N}$ & $54(36.3 \%)$ & $95(63.7 \%)$ & - \\
\hline Sex, male/female & $24 / 30(44.4 \% / 55.6 \%)$ & $23 / 72(24.2 \% / 75.8 \%)$ & 0.01 \\
\hline The median age (range) years & $36(18-61)$ & $30(18-59)$ & 0.1 \\
\hline $\mathrm{Hb}(\mathrm{gr} / \mathrm{dL})$ Mean $\pm \mathrm{SD}$ & $14.9 \pm 1.5$ & $13.5 \pm 1.7$ & $<0.001$ \\
\hline HCT (\%) Mean \pm SD & $43.2 \pm 3.7$ & $39.7 \pm 4.5$ & $<0.001$ \\
\hline MCV (fL) Mean \pm SD & $87 \pm 4$ & $83 \pm 7$ & 0.002 \\
\hline RDW (\%) Mean \pm SD & $13.4 \pm 0.8$ & $14.3 \pm 1.6$ & 0.001 \\
\hline Leukocyte $\left(10^{3} / \mathrm{mm}^{3}\right)$ Mean \pm SD & $8.0 \pm 2.1$ & $6.7 \pm 1.7$ & $<0.001$ \\
\hline Neutrophils $\left(10^{3} / \mathrm{mm}^{3}\right)$ Mean \pm SD & $5.0 \pm 1.8$ & $4.1 \pm 1.6$ & 0.001 \\
\hline Lymphocytes $\left(10^{3} / \mathrm{mm}^{3}\right)$ Mean \pm SD & $2.2 \pm 0.6$ & $2 \pm 0.5$ & 0.04 \\
\hline Thrombocyte $\left(10^{3} / \mathrm{mm}^{3}\right)$ Mean \pm SD & $253 \pm 59$ & $245 \pm 53$ & 0.42 \\
\hline PDW (fL) Mean \pm SD & $16.9 \pm 0.5$ & $16.9 \pm 0.5$ & 0.46 \\
\hline MPV (fL) Mean \pm SD & $8.6 \pm 0.9$ & $8.9 \pm 0.8$ & 0.05 \\
\hline PCT (\%) Mean \pm SD & $216 \pm 51$ & $219 \pm 57$ & 0.71 \\
\hline Ferritin $(\mathrm{ng} / \mathrm{mL})$ Mean \pm SD & $26 \pm 30$ & $20 \pm 28$ & 0.23 \\
\hline Transferrin saturation (\%) Mean \pm SD & $15 \pm 17$ & $12 \pm 13$ & 0.41 \\
\hline
\end{tabular}

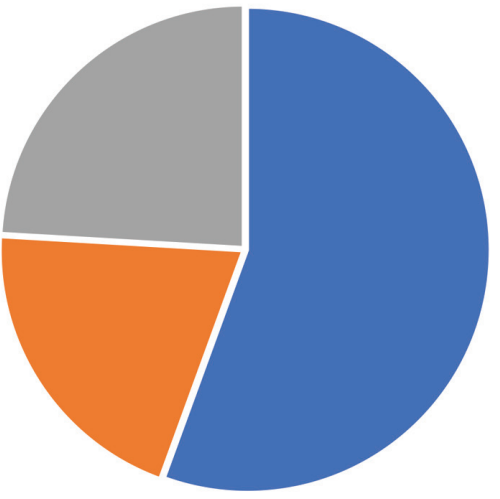

- Mild smokers = Moderate smokers = Heavy smokers

Figure 1. Distribution of intensity of smoking

\section{Discussion}

This study showed that cigarette smoking has adverse effects on hematological parameters such as Hb, HCT, MCV, RDW levels and leukocyte, neutrophil and lymphocyte counts. Hb, HCT, MCV levels and neutrophil and lymphocyte counts were significantly higher in smokers-group when compared to non-smokers group. RDW was significantly lower in smokers-group than in non-smokers group. $\mathrm{Hb}$ and HTC levels were significantly increased with the intensity of smoking. Lakshmi et al. (12) showed that HCT and Hb levels were significantly higher in smokers and red blood cell (RBC) counts were significantly increased as intensity of smoking increased among smokers. Increase in $\mathrm{Hb}$ concentrations is believed to be mediated by exposure to carbon monoxide and some studies suggested that rise in $\mathrm{Hb}$ level in blood of smokers could be a compensatory mechanism (13). The MCV gives us a measure of RBC volume averaged over millions of cells. In contrast to our findings, Pankaj et al. (14) did not find any significant difference in MCV between smokers and non-smokers. Elevated levels of MCV in our study indicate that smokers might suffer from megaloblastic, hemolytic, pernicious or macrocytic anemias usually caused by B12 and folic acid deficiencies.

Increased total leukocyte counts observed in smokersgroup is similar to prior studies. Even though the certain mechanisms of how smoking increases the number of leukocytes are not fully explained, there are several factors for smoking-induced leukocytosis that can be explained in alternative ways $(1,15,16)$. Inflammatory stimulation of the respiratory tract provokes the increase of the inflammatory markers in circulation which influence the number of leukocytes (1). On one hand, total leukocyte and neutrophil counts were not significantly increased as the intensity of smoking increased in the smokers-group. On the other hand, lymphocyte counts were significantly increased with the intensity of smoking. It is reputed that atherogenic effect of cigarette smoking may be partially mediated by leukocytes. Leukocyte count may be the most useful and basic biomarker of endothelium injury. Presence of chronically increased number of leukocytes 
Table 2. Baseline characteristics and comparison of hematological parameters between mild, moderate and heavy smokers

\begin{tabular}{|c|c|c|c|c|}
\hline Parameters & $\begin{array}{l}\text { Mild smokers } \\
\text { (Pack years <10) }\end{array}$ & $\begin{array}{l}\text { Moderate smokers } \\
\text { (Pack years 10-19) }\end{array}$ & $\begin{array}{l}\text { Heavy smokers } \\
\text { (Pack years } \geq 20 \text { ) }\end{array}$ & p \\
\hline $\mathbf{N}$ & $30(55.6 \%)$ & $11(20.4 \%)$ & $13(24.1 \%)$ & \\
\hline Sex, male/female & $10 / 20(33.3 \% / 66.7 \%)$ & $3 / 8(27.3 \% / 72.7 \%)$ & $11 / 2(84.6 \% / 15.4 \%)$ & 0.004 \\
\hline The median age (range) years & $27(18-52)$ & $37(18-54)$ & $45(30-61)$ & $<0.001$ \\
\hline $\mathrm{Hb}(\mathrm{gr} / \mathrm{dL})$ Mean $\pm \mathrm{SD}$ & $14.6 \pm 1.3$ & $14.2 \pm 1.6$ & $15.9 \pm 1.1$ & 0.01 \\
\hline HCT (\%) Mean \pm SD & $42.6 \pm 3.6$ & $41.5 \pm 3.7$ & $45.8 \pm 2.7$ & 0.01 \\
\hline MCV (fL) Mean \pm SD & $86 \pm 4$ & $88 \pm 6$ & $89 \pm 3$ & 0.18 \\
\hline RDW (\%) Mean \pm SD & $13.4 \pm 0.7$ & $13.7 \pm 1$ & $13.2 \pm 0.6$ & 0.5 \\
\hline Leukocyte $\left(10^{3} / \mathrm{mm}^{3}\right)$ Mean \pm SD & $8.0 \pm 2.3$ & $6.9 \pm 2.1$ & $8.9 \pm 1.3$ & 0.05 \\
\hline Neutrophils $\left(10^{3} / \mathrm{mm}^{3}\right)$ Mean \pm SD & $5.1 \pm 2.0$ & $4.2 \pm 1.5$ & $5.5 \pm 1.5$ & 0.21 \\
\hline Lymphocytes $\left(10^{3} / \mathrm{mm}^{3}\right)$ Mean \pm SD & $2.1 \pm 0.5$ & $2 \pm 0.8$ & $2.5 \pm 0.4$ & 0.04 \\
\hline Thrombocyte $\left(10^{3} / \mathrm{mm}^{3}\right)$ Mean \pm SD & $276 \pm 62$ & $217 \pm 49$ & $230 \pm 36$ & 0.01 \\
\hline PDW (fL) Mean \pm SD & $16.8 \pm 0.5$ & $17 \pm 0.5$ & $17 \pm 0.5$ & 0.26 \\
\hline MPV (fL) Mean \pm SD & $8.5 \pm 0.9$ & $8.7 \pm 0.7$ & $8.7 \pm 1$ & 0.63 \\
\hline PCT (\%) Mean \pm SD & $234 \pm 57$ & $187 \pm 37$ & $199 \pm 26$ & 0.02 \\
\hline Ferritin $(\mathrm{ng} / \mathrm{mL})$ Mean \pm SD & $22 \pm 25$ & $27 \pm 32$ & $34 \pm 39$ & 0.96 \\
\hline Transferrin saturation (\%) Mean \pm SD & $15 \pm 18$ & $15 \pm 18$ & $14 \pm 16$ & 0.97 \\
\hline
\end{tabular}

in smokers contributes to pathogenesis of smokingrelated diseases, particularly ischaemic vascular disease. Several studies established that high number of leukocytes represents an independent predictor of atherosclerosis and cardiovascular diseases (17).

Khand et al. (18) compared hematological parameters, C-reactive protein (CRP) and magnesium (Mg) levels between smokers and non-smokers. They showed that neutrophil counts were lower in contrast to our findings and lymphocyte counts were higher in smokers. They also showed that smoking significantly decreased serum magnesium concentration and increased serum CRP concentration. Platelets are the key elements playing a role in the processes of hemostasis, inflammation and tissue repair. Patients with chronic inflammatory or malignant diseases often develop reactive thrombocytosis (19). Therefore, we would expect a significant difference in terms of platelet indices between smokers and nonsmokers. However, the platelet indices were similar between smokers and non-smokers groups in this study. In inflammatory conditions, ferritin may increase as an acute phase reactant (20). Therefore, we compared serum ferritin level and TS between smokers and non-smokers. However, there were no significant differences in TS and ferritin levels between the two groups.

\section{Study Limitations}

Our study has some limitations. First of all, this study was designed in a retrospective fashion. Secondly, the number of patients involved in the study was limited. Additionally, the laboratory parameters examined in the study were limited. There was an imbalance in gender ratio in the smoking group. However, when we look at the general population in Turkey, we know that men have a higher smoking rate.

\section{Conclusion}

Our study showed that cigarette smoking has severe adverse effects on hematological parameters such as $\mathrm{Hb}$, leucocytes, lymphocytes, MCV and HCT. These alterations might be associated with a greater risk for developing secondary polycythemia, atherosclerosis, chronic obstructive pulmonary disease and cardiovascular diseases. Hb, HTC, leukocyte and lymphocytes were significantly increased with the intensity of smoking. More intense smoking may increase the risk of developing such diseases.

\section{Authorship Contributions}

Concept: S.A. Design: I.C.H. Data Collection or Processing: A.G. Analysis or Interpretation: R.Ç. Literature Search: R.Ç. Writing: R.Ç.

Conflict of Interest: The authors of this paper have no conflict of interests, including specific financial interests, relationships, and/or affiliations relevant to the subject matter or materials included.

Financial Disclosure: The authors declared that this study received no financial support. 


\section{References}

1. Malenica M, Prnjavorac B, Bego T, et al. Effect of Cigarette Smoking on Haematological Parameters in Healthy Population. Med Arch 2017;71:132-6.

2. Lu JT, Creager MA. The relationship of cigarette smoking to peripheral arterial disease. Rev Cardiovasc Med 2004;5:189-93.

3. Law MR, Morris J, Wald NJ. Environmental tobacco smoke exposure and ischaemic heart disease: an evaluation of the evidence. BMJ 1997;315:973-80.

4. Messner B, Bernhard D. Smoking and Cardiovascular DiseaseSignificance: Mechanisms of Endothelial Dysfunction and Early Atherogenesis. Arterioscler Thromb Vasc Biol 2014;34:509-15.

5. Shah RS, Cole JW. Smoking and stroke: the more you smoke the more you stroke. Expert Rev Cardiovasc Ther 2010;8:917-32.

6. M Lappé J, Horne B, H Shah S, et al. Red cell distribution width, C-reactive protein, the complete blood count, and mortality in patients with coronary disease and a normal comparison population. Clin Chim Acta 2011;412:2094-9.

7. Yeung MC, Buncio AD. Leukocyte count, smoking, and lung function. Am J Med 1984;76:31-7.

8. Friedman GD, Siegelaub AB, Seltzer CC, Feldman R, Collen MF. Smoking habits and the leukocyte count. Arch Environ Health 1973;26:137-43

9. Aktas G, Cakiroglu B, Sit M, et al. Mean platelet volume: a simple indicator of chronic prostatitis. Acta Medica Mediterranea 2013;29:551-4.

10. Surgit $O$, Pusuroglu $H$, Erturk $M$, et al. Assessment of mean platelet volume in patients with resistant hypertension, controlled hypertension and normotensives. Eurasian J Med 2015;47:79-84.
11. Meenakshisundaram R, Rajendiran C, Thirumalaikolundusubramanian P. Lipid and lipoprotein profiles among middle aged male smokers: a study from southern India. Tob Induc Dis 2010;8:11.

12. Lakshmi A, Anandhi Lakshmanan GKP, Saravanan A. Effect of intensity of cigarette smoking on haematological and lipid parameters. J Clin Diagn Res 2014;8:BC11-3.

13. Aitchison R, Russell N. Smoking-a major cause of polycythaemia. J R Soc Med 1988;81:89-91.

14. Pankaj J, Reena J, Mal K, Ketan M. Effect of cigarette smoking on hematological parameters: comparison between male smokers and no smokers. IJSN 2014;5:740-3.

15. Higuchi T, Omata F, Tsuchihashi K, Higashioka K, Koyamada $\mathrm{R}$, Okada $\mathrm{S}$. Current cigarette smoking is a reversible cause of elevated white blood cell count: Cross-sectional and longitudinal studies. Prev Med Rep 2016;4:417-22.

16. Inal B, Hacıbekiroglu T, Cavus B, Musaoglu Z, Demir H, Karadag B. Effects of smoking on healthy young men's hematologic parameters. North Clin Istanb 2014;1:19-25.

17. Madjid M, Awan I, Willerson JT, Casscells SW. Leukocyte count and coronary heart disease: implications for risk assessment. J Am Coll Cardiol 2004;44:1945-56.

18. Khand F, Shaikh SS, Ata MA, Shaikh SS. Evaluation of the effect of smoking on complete blood counts, serum C-reactive protein and magnesium levels in healthy adult male smokers. J Pak Med Assoc 2015;65:59-61.

19. Klinger $\mathrm{MH}$, Jelkmann W. Role of blood platelets in infection and inflammation. J Interferon Cytokine Res 2002;22:913-22.

20. Goot K, Hazeldine S, Bentley P, Olynyk J, Crawford D. Elevated serum ferriti: What should GPs know? Aust Fam Physician 2012;41:945-9. 